\title{
Ortopeder i lommen på industrien
}

\author{
Utviklingen av nye ortopediske produkter er avhengig av tett samarbeid mellom ortopedene og industrien. \\ De siste årene er det imidlertid blitt avdekket en rekke tilfeller av økonomisk samrøre mellom industrien og \\ deler av det ortopediske fagmiljø i USA. Dette har aktualisert spørsmålet om i hvilken grad ortopedirelatert \\ forskning og utvikling kan ha vært påvirket av uheldige økonomiske incentiver.
}

Engelsk oversettelse av hele artikkelen på www.tidsskriftet.no

\section{Robin Holtedahl}

robi-hol@online.no

Avdeling for fysikalsk medisin og rehabilitering Sykehuset Buskerud

og

Doktor Holtedahls spesialistpraksis

Interessekonflikter oppstår i det øyeblikk ortopeden, eller avdelingen vedkommende arbeider i, oppnår økonomisk fordel av å promotere eller ta i bruk ett bestemt produkt. I sin mest ekstreme form kan det dreie seg om å motta godtgjørelse for konsulentoppdrag, salgsprovisjoner for et produkt man har vært med på å utvikle (royalties), aksjer eller opsjoner i firmaet. I de senere år er det blitt avdekket en rekke eksempler på slike økonomiske koblinger, først og fremst blant ortopeder i USA. Samtidig som samarbeid med industrien er av avgjørende betydning for utvikling, klinisk implementering og evaluering av ortopediske implantater, vil eventuelle interessekonflikter hos samarbeidende ortopeder kunne føre til svekket kvalitetssikring i ett eller flere ledd. Dette kan i så fall tenkes å føre til økt risiko for uheldige behandlingsutfall, også for norske pasienter operert med slikt utstyr.

\section{Er operasjonsresultatet avhengig av finansieringskilden?}

I den grad ortopediske implantater blir underlagt kliniske studier, er disse kjennetegnet av å være små og ha kort oppfølgingstid. I kontrast til studier på legemidler utgjør randomiserte kliniske studier mellom $6 \%$ og $21 \%$ av samtlige publiserte artikler i ortopediske tidsskrifter $(1,2)$. Den ortopedirelaterte forskningen i USA er i økende grad blitt avhengig av private midler. $75 \%$ av kliniske studier på hofteleddsproteser er industrifinansierte (3). Forholdet mellom offentlig og privat finansiering av ortopedisk forskning endret seg fra $73: 27$ i 1999 til 57 : 43 i 2002, og andelen industrirelaterte interessekonflikter blant amerikanske ortopeder økte fra 3\% i 1985 til 39\% i 2002 (4).

I randomiserte kirurgiske studier med industrien som oppdragsgiver rapporteres det åtte ganger oftere signifikant positive utfall enn i studier som er offentlig finansiert (5). I artikler som omhandlet ryggkirurgi i tidsskriftet Spine var tilsvarende oddsratio 4,5 (6). Diskrepansen ble forklart med blant annet skjevheter i studiedesign og tolking av resultater samt forsinket eller manglende publisering.

Innen leddkirurgien er forskjellene muligens enda større. Ezzet fant at godt resultat etter hoftealloplastikk ble rapportert i $96 \%$ av industrifinansierte studier, mot $41 \%$ i studier uten slik finansiering, mens dårlig utfall ble rapportert i henholdsvis $2 \%$ og $59 \%$ av studiene (3). I kneprotesestudier var det bra utfall $\mathrm{i}$ henholdsvis $72 \% \mathrm{og}$ $18 \%$, uheldig utfall i henholdsvis $16 \%$ og $83 \%$. Slike forskjeller var særlig uttalt i studier fra USA, men også de fleste øvrige studier viste samme tendens. Mye tyder også på at kirurgiske fagtidsskrifter, særlig de med høy impaktfaktor, vegrer seg mot å publisere studier med negative eller inkonklusive resultater, hvilket medfører publikasjonsskjevhet (2).

\section{Bestikkelser fra de «fem store»}

I 2005 initierte justisdepartementet i USA en gransking av økonomiske forbindelser mellom ortopeder og de fem største produsenter av ortopedisk utstyr, som samlet står for $90 \%$ av produksjonen av hofte- og kneproteser i USA (Zimmer, Biomet, DePuy, Smith \& Nephew og Stryker). Hensikten med granskingen var å avdekke om det var utbetalt ulovlige provisjoner (kickbacks) for ortopediske inngrep som ble dekket over offentlige helsebudsjetter (Medicare dekker omtrent to tredeler av utgifter til hofte- og kneproteser i USA). Det ble avdekket avtaler mellom firmaene og en rekke ortopeder som mellom 2002 og 2006 hadde mottatt til dels betydelige pengebeløp og gaver dersom de valgte disse firmaenes produkter. Det fremkom også at ortopeder ofte unnlot å informere både arbeidsgiver og pasientene de behandlet om sine økonomiske interesser (7). For å unngå strafferettslig forfølgelse og videre grans- king inngikk de fem produsentene høsten 2007 forlik med statsadvokaten. De fikk bøter på til sammen 310 millioner dollar og ble underlagt overvåking fra representanter for de føderale helsemyndigheter i en prøveperiode på 18 måneder. De måtte også offentliggjøre alle utbetalinger til samarbeidende ortopeder. I mars 2009 kunngjorde justisdepartementet at prøvetiden var «bestått», og straffesakene ble frafalt.

Basert på listene over utbetalinger til leger som de fem selskapene var blitt pålagt å offentliggjøre, undersøkte Chimonas og medarbeidere i hvilken grad slike godtgjørelser ble omtalt i publiserte artikler som omhandlet firmaenes produkter. Av 41 ortopeder som hadde mottatt mer enn 1 million dollar i løpet av 2007, hadde 32 publisert artikler i løpet av 2008 (8). Blant til sammen 95 inkluderte artikler varierte graden av oppgitte interessekonflikter betydelig, men i $54 \%$ av artiklene hadde forfatteren unnlatt å gi opplysninger om økonomiske bidrag. Ingen av tidsskriftene oppga størrelsen på bidraget, men ett (Journal of Joint and Bone Surgery, med sju artikler) oppga hvorvidt beløpet oversteg 10000 dollar. Det var ingen sammenheng mellom tidsskriftets offisielle retningslinjer vedrørende åpenhet om interessekonflikter og faktiske oppgitte interessekonflikter. Førsteforfattere oppga interessekonflikter noe oftere enn øvrige forfattere ( $54 \%$ versus $32 \%$ ).

Okike og medarbeidere (9) sammenholdt opplysninger om utbetalinger med andelen av ortopeder som oppga slik økonomisk godtgjøring $\mathrm{i}$ forbindelse med presentasjoner eller styredeltakelse på det nasjonale årsmøtet for amerikanske ortopeder. Av disse var det ca. $21 \%$ som unnlot å rapportere om økonomiske godtgjørelser for produkter som hadde direkte tilknytning til innlegget, tilsvarende $50 \%$ der produktet kun hadde indirekte tilknytning.

\section{Interessekonflikter innen ryggkirurgi}

Medtronic er en av verdens største produsenter av medisinskteknisk utstyr og den største leverandør av ryggimplantater. 


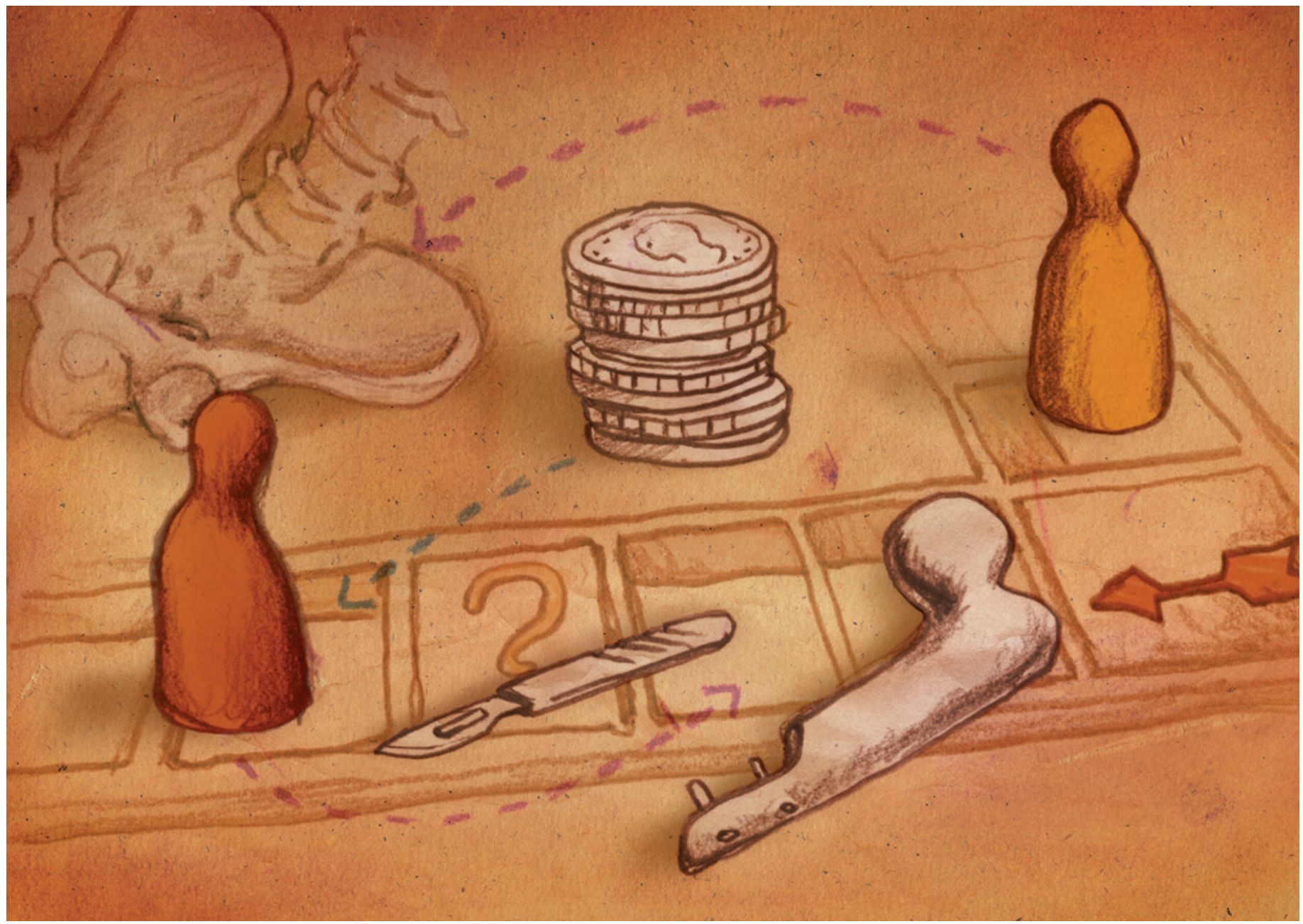

I 2006 varslet to tidligere ansatte de føderale myndighetene om omfattende skjulte økonomiske bidrag til en rekke ortopeder fra og med 1998, i den hensikt å påvirke dem til benytte firmaets implantater (10). Departementet fant dokumentasjon på omfattende økonomiske misligheter, blant annet at firmaet hadde inngått fiktive, men godt honorerte konsulentavtaler med en rekke ortopeder. Medtronic inngikk i 2006 forlik med justisdepartementet, der selskapet ble idømt en bot på 40 millioner dollar, dog uten at firmaet vedkjente at utbetalingene hadde vært lovstridige.

Medtronic er produsenten av Infuse, et såkalt rekombinant beinmorfogent protein-2, som brukes sammen med et implantat (LT-bur) ved lumbale enkeltnivåfiksasjoner. Det omdanner bindevev til beinvev, slik at kirurgen slipper å høste bein fra hoftekammen. FDA godkjente produktet i 2002 til bruk ved lumbale fiksasjoner med fremre tilgang, basert på en randomisert studie (11). I artikkelen er det ikke nevnt at forfatterne mottok royalties for øvrige av firmaets produkter. Det kom senere frem at $25 \%$ av pasientene i denne studien ble operert av ortopeder med økonomisk tilknytning til Medtronic. Disse rapporterte en suksessrate på $80 \%$, mot $63 \%$ suksess der kirurgen ikke hadde noen slik tilknytning (12).

I 2004 ble det publisert ytterligere en randomisert multisenterstudie om Infuse brukt som supplement til titanbur (13). Studien måtte avbrytes prematurt på grunn av overraskende høy forekomst av postoperativ beindanning intraspinalt. Man fant signifikant effekt på kun ett av de definerte endepunktene. Trass i dette ble teknikken betegnet som «lovende». Av senere frigitte lister fra Medtronic fremgikk det at tre av de fire forfatterne mottok royalty på til sammen nesten 4 millioner dollar fra firmaet for øvrige Medtronic-produkter (14). FDA har senere medgitt at byrået allerede før godkjenningen hadde kjennskap til interessekonflikter hos de involverte ortopeder, men så langt har de unnlatt å offentliggjøre opplysningene (12). I 13 publiserte industrifinansierte Infuse-studier med til sammen 780 pasienter ble det ikke rapportert noen komplikasjoner, mens en gruppe uavhengige forskere som innhentet data om det samme materialet fra bl.a. FDA, påviste en komplikasjonsrate på opptil $50 \%$ (15).

\section{Lumbale skiveproteser}

Lumbale skiveproteser ble utviklet som et alternativ til konvensjonell fiksasjon med tanke på å opprettholde bevegeligheten i det opererte skivenivå. En av disse er Prodiscprotesen, som i USA første gang ble operert inn av Jack E. Zigler ved Texas Back Institute i 2001. Året etter investerte han minst 25000 dollar i et datterselskap som finansierte produktutvikling av protesen. Øvrige samarbeidende ortopeder investerte også store beløp i selskapet, samtidig som de opererte inn Prodisc-proteser (16). Den amerikanske Prodisc-produsenten ble i 2003 kjøpt opp av det sveitsiske firmaet Synthes for 175 millioner dollar, med avtale om dobling av beløpet dersom FDA godkjente protesen.

I 2001 initierte Synthes en randomisert multisenterstudie av Prodisc-protesen, der Texas Back Institute sammen med 18 andre ortopediske sentre deltok. Basert på preliminære data fra studien godkjente FDA protesen i 2006. I 2007 ble studien publisert i tidsskriftet Spine (17). Gjennom etterforskning og senere høringer under statsadvokaten i New Jersey i 2009 kom det frem at omtrent halvparten av de deltakende ortopeder i studien hadde investeringer i firmaet da studien pågikk, noe som ikke fremgikk av godkjenningssøknaden til FDA (18). Medtronic ble i et forlik pålagt å offentliggjøre alle fremtidige utbetalinger til samarbeidende leger og unnlate å utdele 
aksjer eller opsjoner. Statsadvokaten kritiserte FDA for ikke å ha forsøkt å oppspore interessekonflikter før godkjennelsen og anbefalte skjerpede kontrolltiltak.

\section{En mann med flere hatter}

En av de involverte ortopedene i den omtalte Medtronic-dommen i 2006 var Thomas Zdeblick ved universitetet i Wisconsin. I 1998 tegnet han en tiårskontrakt med Medtronic om å arbeide som konsulent åtte dager $\mathrm{i}$ året mot en årlig godtgjørelse på 400000 dollar. Pasientene ved universitetsklinikken ble ikke informert om at han mottok lønn fra firmaet (19). Til sin arbeidsgiver oppga han å ha mottatt mellom 20000 og 40000 dollar fra Medtronic årlig. Etter at Medtronic ble pålagt å legge frem lister over utbetalinger til leger, kom det frem at Zdeblick i årene 2003-07 hadde mottatt over 19 millioner dollar for royalties knyttet til Medtronic-produkter, inkludert LT-buret.

Zdeblick ble sjefredaktør i Journal of Spinal Disorders and Techniques i 2002, og sitter ifølge tidsskriftet fortsatt i stillingen (20). Tidsskriftet opplyser ikke om redaktørens tilknytning til Medtronic. Under Zdeblicks redaktørperiode har det $i$ hvert nummer vært minst én artikkel som omhandler Medtronic-produkter (21).

I seks artikler var Zdeblick medforfatter, to av disse omhandlet Infuse. Ikke i noen av artiklene var det oppgitt noe om økonomiske interessekonflikter.

Et forfattersøk på Thomas Zdeblick i Pubmed for perioden 1.1. 2002-8.5. 2011 viser at han har vært (med)forfatter av 16 artikler i fagfellevurderte tidsskrifter. 13 av disse omhandlet Medtronic-produkter (tab 1). I seks artikler var det ingen omtale av Zdeblicks interessekonflikter, og i én ble slike konflikter benektet. I de resterende seks var interessekonfliktene omtalt i kryptiske vendinger, uten opplysninger om konkrete beløp og i liten grad om type godtgjørelse.

\section{Vil trollet sprekke i solen?}

I denne kronikken har jeg trukket frem en del eksempler på manglende transparens og etisk tvilsomt økonomisk samrøre mellom deler av amerikansk ortopedisk fagmiljø og produsenter av ortopedisk utstyr. Valg og anvendelse av implantater i klinisk virksomhet er i stor grad basert på resultater frembrakt gjennom industrifinansiert forskning. Man kan ikke nødvendigvis ta for gitt at slike studier beskriver produktets eller prosedyrens egenskaper på en objektiv og upartisk måte. Selv om det er vanskelig å dokumentere noen direkte sammenheng mellom økonomiske interessekonflikter og uheldige behandlingsutfall, vil tilliten til at produktet holder mål kunne svekkes dersom forskerens eller kirurgens integritet kan trekkes i tvil. Problemene forsterkes ytterligere når kontrollmyndighetene er mer opptatt av rask godkjenning enn av grundig evaluering.

Det er nylig lansert konstruktive forslag til tiltak som anses som helt nødvendige for å bedre industriens og det kirurgiske fagmiljøs omdømme $(22,23)$. Det er av ledende amerikanske ortopeder blitt foreslått at alle ortopediske produkter skal avgiftsbelegges og at overskuddet fra dette skal gå inn i et fond som skal støtte produsentuavhengig forskning. Foreningen av amerikanske ortopeder (AOA) etablerte i 2008 et slikt produsentuavhengig fond, OmeGA, og så langt har fire produsentfirmaer skutt inn midler i fondet (Zimmer, Smith \& Nephew, Synthes og Integra). Med tanke på faren for publikasjonsskjevhet er det også lansert forslag om obligatorisk registrering av alle kliniske forsøk med implantater, på linje med det som gjøres når det gjelder farmakologiske produkter (24).

Physician Payment Sunshine Act ble vedtatt i den amerikanske kongressen i mars 2010. Loven pålegger produsenter å rapportere de fleste typer bidrag til leger. I tillegg må legers medeierskap i selskaper samt økonomisk støtte til produktrelatert forskning rapporteres. Myndighetene krever nå årlig innrapportering av bidrag til leger overstigende 100 dollar fra og med mars 2011. Føderal lovgiving vil kreve full

Tabell 1 Artikler i fagfellevurderte tidsskrifter med Thomas Zdeblick som hoved- eller medforfatter som omhandler kliniske fors øk der Medtronic produkter er benyttet. Artiklene er identifisert gjennom forfatters $\varnothing$ k i PubMed for perioden 1.1. 2002-8.5. 2011

\begin{tabular}{|c|c|c|c|c|c|c|}
\hline Tidsskrift & $\AA$ & $\begin{array}{l}\text { Første- } \\
\text { forfatter }\end{array}$ & $\begin{array}{l}\text { Produkt } \\
\text { beskrevet }\end{array}$ & $\begin{array}{l}\text { Medtronic- } \\
\text { produkt }\end{array}$ & $\begin{array}{l}\text { Interesse- } \\
\text { konflikt nevnt }\end{array}$ & Opplysninger om bidrag fra Medtronic \\
\hline J Spin Dis Tech & 2002 & Burkus & $\mathrm{Ja}$ & Rht-bmp2 & Nei & - \\
\hline J Spin Dis Tech & 2003 & Burkus & Ja & Infuse & Nei & - \\
\hline J Spin Dis Tech & 2005 & Schuler & Ja & LT-bur & Nei & - \\
\hline J Spin Dis Tech & 2006 & Ragab & $\mathrm{Ja}$ & Cervikal plate & Nei & - \\
\hline J Spin Dis Tech & 2009 & Jensen & $\mathrm{Ja}$ & Cervikal plate & Nei & - \\
\hline Eur Spine J & 2005 & Le Huec & Ja & $\begin{array}{l}\text { Maverick } \\
\text { skiveprotese }\end{array}$ & Nei & - \\
\hline Orthopedics & 2004 & Burkus & $\mathrm{Ja}$ & Rht-bmp2 & Ja & Har finansielle interesser i Medtronic \\
\hline Spine & 2003 & Zdeblick & Ja & LT-bur, Infuse & Ja & $\begin{array}{l}\text { En eller flere av forfatterne har mottatt eller vil motta } \\
\text { godtgjørelse for personlig eller profesjonell bruk fra en } \\
\text { kommersiell part som har direkte eller indirekte } \\
\text { tilknytning til manuskriptets innhold }\end{array}$ \\
\hline J Bone Joint Surg Am & 2009 & Burkus & Ja & Rht-bmp2 & Ja & $\begin{array}{l}\text { Til støtte for deres forskning eller tilrettelegging av dette } \\
\text { arbeid har en eller flere av forfatterne mottatt, i minst ett } \\
\text { år, eksterne midler eller bidrag overstigende } 10000 \text { dollar } \\
\text { fra Medtronic }\end{array}$ \\
\hline J Bone Joint Surg Am & 2008 & Riew & Ja & $\begin{array}{l}\text { Prestige } \\
\text { skiveprotese }\end{array}$ & Ja & $\begin{array}{l}\text { Til støtte for deres forskning eller tilrettelegging av dette } \\
\text { arbeid har en eller flere av forfatterne mottatt, i minst ett } \\
\text { år, eksterne midler eller bidrag overstigende } 10000 \text { dollar } \\
\text { fra Medtronic }\end{array}$ \\
\hline J Neurosurg Spine & 2007 & $\begin{array}{l}\text { Mum- } \\
\text { maneni }\end{array}$ & $\mathrm{Ja}$ & $\begin{array}{l}\text { Prestige } \\
\text { skiveprotese }\end{array}$ & $\mathrm{Ja}$ & $\begin{array}{l}\text { Forfatterne har mottatt eller vil motta godtgjørelser for } \\
\text { personlig eller profesjonell bruk fra Medtronic i forbindelse } \\
\text { med produkter omtalt i artikkelen }\end{array}$ \\
\hline Orthop Clin N Am & 2004 & Burkus & $\mathrm{Ja}$ & Interfix bur & $\mathrm{Ja}$ & $\begin{array}{l}\text { To av forfatterne er konsulenter i Medtronic, og dr. Zdeblick } \\
\text { mottar royalties fra Medtronic }\end{array}$ \\
\hline Spine J & 2004 & Mathews & $\mathrm{Ja}$ & $\begin{array}{l}\text { Maverick } \\
\text { skiveprotese }\end{array}$ & Nei & $\begin{array}{l}\text { Ingenting av verdi er mottatt fra kommersielle kilder } \\
\text { relatert til denne forskning }\end{array}$ \\
\hline
\end{tabular}


åpenhet om økonomiske overføringer til leger og forskningsinstitusjoner innen 2013. FDA er nå i ferd med å innskjerpe godkjenningsprosedyrene for medisinskteknisk utstyr. Også innen EØS-området er det kommet skjerpede direktiver vedrørende avviksrapportering (25) og ytterligere krav om kvalitetssikring fra mars 2010.

Dersom man lykkes med å bygge opp produsentuavhengige forskningsmiljøer, bør det være håp om at dette vil generere forskningsresultater som er til å stole på. Dette vil dermed bidra til kvalitetssikring av ortopediske implantater.

\section{Robin Holtedahl (f. 1948)}

er spesialist i fysikalsk medisin og rehabilitering og praktiserende spesialist. Ingen oppgitte interessekonflikter.

\section{Litteratur}

1. Obremskey WT, Pappas N, Attallah-Wasif E et al. Level of evidence in orthopaedic journals. J Bone Joint Surg Am 2005; 87: 2632-8.

2. Kanaan Z, Galandiuk S, Abby M et al. The value of lesser-impact-factor surgical journals as a source of negative and inconclusive outcomes reporting. Ann Surg 2011; 253: 619-23.

3. Ezzet KA. The prevalence of corporate funding in adult lower extremity research and its correlation with reported results. J Arthroplasty 2003; 18 (suppl 1): 138-45

4. Zuckerman JD, Prasarn M, Kubiak EN et al. Conflict of interest in orthopaedic research. J Bone Joint Surg Am 2004: 86-A: 423-8.

5. Bhandari M, Busse JW, Jackowski D et al. Asso ciation between industry funding and statistically significant pro-industry findings in medical and surgical randomized trials. CMAJ 2004; 170: 477-80.

6. Shah RV, Albert TJ, Bruegel-Sanchez V et al. Industry support and correlation to study outcome for papers published in Spine. Spine 2005; 30 : 1099-104, discussion 1105

7. Justice Department recovers $\$ 2$ billion for fraud against the government in Fy 2007; more than $\$ 20$ billion since 1986. www.justice.gov/opa/pr/2007/ November/07 civ 873.html (8.5.2011).

8. Chimonas S, Frosch Z, Rothman DJ. From disclosure to transparency: the use of company payment data. Arch Intern Med 2011; 171: 81-6.

9. Okike K, Kocher MS, Wei EX et al. Accuracy of conflict-of-interest disclosures reported by physicians. N Engl J Med 2009; 361: 1466-74.

10. Carreyrou J, McGinty T. Top spine surgeons reap royalties, Medicare bounty. Wall Street Journal 20.12.2010

11. Burkus JK, Gornet MF, Dickman CA et al. Anterior lumbar interbody fusion using rhBMP-2 with tapered interbody cages. J Spinal Disord Tech 2002; 15 $337-49$.

12. Fauber, J. Trial with questionable results. Journal Sentinel 26.12.2010

13. Haid RW Jr, Branch CL Jr, Alexander JT et al. Pos terior lumbar interbody fusion using recombinant human bone morphogenetic protein type 2 with cylindrical interbody cages. Spine J 2004; 4: 527-39.

14. Fauber J. Doctors question journal articles. Medtronic paid surgeons millions for other products. Journal Sentinel 26.12.2010.
15. Carragee EJ, Hurwitz EL, Weiner BK. A critical review of recombinant human bone morphogenetic protein-2 trials in spinal surgery: emerging safety concerns and lessons learned. Spine J 2011: 11: 471-91.

16. Abelson R. Financial ties are cited as issue in spine study. New York Times 30.1.2008.

17. Zigler J, Delamarter R, Spivak JM et al. Results of the prospective, randomized, multicenter Food and Drug Administration investigational device exemption study of the ProDisc- $L$ total disc replacement versus circumferential fusion for the treatment of 1-level degenerative disc disease. Spine 2007; 32: 1155-62, discussion 1163.

18. Abelson R. Suit says spinal disk maker falsely won F.D.A. approval. New York Times 22.2.2008.

19. Fauber J. Doctors face pressure to disclose all side pay. Journal Sentinel Online 11.1.2009.

20. htpp: //journals.lww.com/jspinaldisorders/pages/ aboutthejournal.aspx (4.7.2011).

21. Fauber J. Journal editor gets royalties as articles favor devices. Journal Sentinel 24.12.2009.

22. Healy WL, Peterson RN. Department of Justice investigation of orthopaedic industry. J Bone Joint Surg Am 2009; 91: 1791-805.

23. Gelberman RH, Samson D, Mirza SK et al. Orthopaedic surgeons and the medical device industry: the threat to scientific integrity and the public trust. J Bone Joint Surg Am 2010; 92: 765-77.

24. Sim I. Trial registration for public trust: making the case for medical devices. J Gen Intern Med 2008; 23 (suppl 1): $64-8$

25. Donawa M. Implementing new European vigilance procedures. Med Device Technol 2007; 18: 34 . 36-7.

Mottatt 9.5. 2011, første revisjon innsendt 9.7 2011, godkjent 4.8. 2011. Medisinsk redaktør Are Brean. 